\title{
P.LOND.LIT. 207 AND THE ORIGIN OF THE NOMINA SACRA: A TENTATIVE PROPOSAL ${ }^{1}$
}

\author{
Don C. Barker
}

\begin{abstract}
The origin and development of the nomina sacra (sacred names written in an abbreviated form) found in early Christian texts is much debated in scholarly circles and no agreement has been reached. However the use of the nomina sacra in P.Lond.Lit. 207 may help to resolve some of the questions that surround the puzzle of their origin. P.Lond.Lit. 207 is a portion of papyrus that has broken off from a roll $(24.5 \times 25.7 \mathrm{~cm})$, covering Psalms 11(12):7 to 14(15):4. The scribe of P.Lond.Lit. 207 has consistently written Kurios in an abbreviated form (nomen sacrum), giving only the first and last letters, and a supralinear bar drawn above the abbreviation. On the other hand, Theos is always written uncontracted. This is quite unusual given that Theos in Christian texts is always written as a nomen sacrum. Could the reason for this practice in P.Lond.Lit. 207 be found in the Semitic custom of contracting personal names to the first and last letter? Is Kurios abbreviated in this Semitic fashion to notify the reader that the word is being used to translate the personal name (the Tetragrammaton) of the Hebrew deity?
\end{abstract}

\section{Introduction}

Contractions of certain 'sacred names' known as nomina sacra have been identified in early Christian texts. The primary names to be treated in this way are: kú@ı 'I ways. Firstly suspension; that is the first two letters of the name are written and the rest are suspended. The second is contraction; the first and last letters are written and the rest are omitted. The third is 'complex' contraction; the first and last letters are written as well as some other letters. After the scribe wrote the abbreviated form a supralinear bar was placed over the name, which was a common scribal indicator, signifying that the letters below are abbreviated.

The origin and development of the nomina sacra is much debated in scholarly circles and no agreement has been reached. Ludwig Traube, who first called these contractions nomina sacra, thought that their origin was to be found in the context of Hellenistic Jews needing a Greek equivalent for the Hebrew Tetragrammaton. ${ }^{2}$ Paap rejected Traube's suggestion and attributed their origin to Jewish Christians, because for them, according to Paap, the Greek word for "God" had exactly the same value as the Tetragrammaton and

\footnotetext{
${ }^{1}$ This paper was first presented at the 24th International Congress of Papyrologists, Helsinki, 2004, since then it has been revised and I am in debt to Prof. L. Hurtado whose British Academy of Humanities grant allowed me to give a revised version to a special conference held at Edinburgh University, June 2005. It is an expansion and further development of the paper 'The Nomina Sacra in P.Lond.Lit.207' in Proceedings of the 24th International Congress of Papyrology, Helsinki, 1-7 August, 2004 (Helsinki: Societas Scientiarum Fennica, 2007, 93-100).

2 Traube 1907.
} 
for that reason was entitled to a distinction in its written forms. ${ }^{3}$ Schuyler Brown arguing for a Christian origin for the nomina sacra rightly observes that it was kúpıos and not $\theta \varepsilon o ́ s$ which was used to represent the Tetragrammaton. He argued that the initial contraction of kúptos was quickly extended in one direction to $\theta \varepsilon$ có

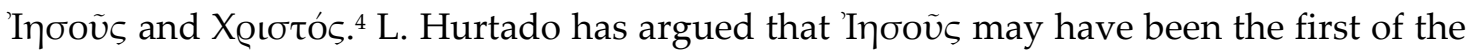
nomina sacra and that its origin lay in the Christians' special reverence for the name of Jesus. ${ }^{5}$ More recently P. Comfort proposes that the practice arose for one of two reasons: a Jewish Christian or Gentile Christian scribe(s) created a nomen sacrum form for kú @ios which was used for a substitute for the Tetragrammaton in the Greek Old Testament or the practice was established to distinguish the word kv́pıos when used of Jesus from its use in Hellenistic literature to describe a particular god or Caesar. ${ }^{6}$ All of these proposals lack hard evidence and remain conjectures.

The use of the nomina sacra in P.Lond.Lit. 207 may help in resolving some of the questions that surround the puzzle of their origin. The treatment of the nomina sacra in P.Lond.Lit. 207 is highly unusual as it treats kúpıos as a nomen sacrum but not $\theta \varepsilon$ cós, which is written consistently without contraction. ${ }^{7}$ This suggests that P.Lond.Lit. 207 conveys evidence for an early origin of the nomina sacra: that it was used initially to distinguish кúpıos, when used as the equivalent for the Hebrew Tetragrammaton, from its normal impersonal use as master or lord.

\section{P.Lond.Lit. 207}

P.Lond.Lit. 207 is a portion of papyrus that has broken off from a roll $(24.5 \times 25.7 \mathrm{~cm})$, covering Psalms 11 (12): 7 to 14 (15): $4 .^{8}$ There is a very clear sheet join down the left side of the papyrus. This explains why, in a number of lines, groups of letters are lost at the beginning of lines. The hand is reformed documentary exhibiting the influence of the chancery style especially with the large initial letters. ${ }^{9}$ The letters are upright and cursive. Epsilon is curved and written in three strokes. The middle vertical stroke of the omega is written at the same height as the others. Omicron is written variously. The $\varepsilon \theta$ or group of letters are mostly rounded rather than narrow and oval. The style is similar to some third century hands such as P.Oxy. 51 3614, which is a documentary text, written in a rounded cursive

\footnotetext{
${ }^{3}$ Paap 1959: 174. P. Comfort has been the latest scholar to advance this suggestion as a possible origin for the practice (2005: $199 \mathrm{ff}$.).

${ }^{4}$ Brown 1970: 18.

${ }^{5}$ Hurtado 1998: 655-73.

${ }^{6}$ Comfort 2005: 199-212.

${ }^{7}$ In four other LXX papyrus manuscripts $\theta \varepsilon$ ó $\varsigma$ is uncontracted, P.Oxy 656 11/111, Stud Pal 114 111/IV, P.Lond.Lit. $211 \mathrm{IV}$. As kúpıos does not appear in these manuscripts it is difficult to know if it was treated as a nomen sacrum.

${ }^{8}$ Ed. anon., Athenaeum, 8 Sept. 1894, 319-321, see also Kenyon 1900. For my transcription of P.Lond.Lit. 207 see the appendix.

${ }^{9}$ Roberts (1979: 16) notes that the enlargement of initial letters was common in documentary texts as well as in Christian texts. That this same phenomenon occurs in some teachers' models is noted by Cribiore (1996: 108).
} 
hand, containing two extracts from a judgement delivered by Septimius Severus in Alexandria in the early part of 200. The resemblance of the hand of P.Lond.Lit. 207 to P.Oxy. 513614 suggests a third century date. ${ }^{10}$ Punctuation and other reading helps are used, such as an apostrophe between double letters, diaeresis over the iota and medial stops between some words.

A number of corrections to the text by other hands are evident. The omicron in col. i 3 has been blotted out and replaced incorrectly by another hand with a supralinear omega (fig. 1). When compared to how the first hand formed an omega, it is obvious that a different hand to that of the original text has written this omega. For example in the line above (fig. 2) the omega is written in a looped cursive style with all verticals written at the same height whilst the inserted omega has a very small almost nonexistent middle vertical stroke. Another hand has clumsily inserted a tau between the kappa and the epsilon in col. ii 13 (fig. 3).

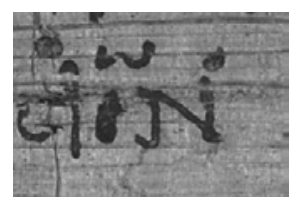

fig. 1

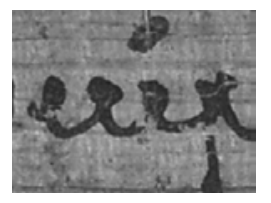

fig. 2

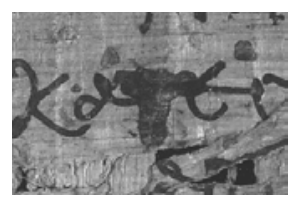

fig. 3

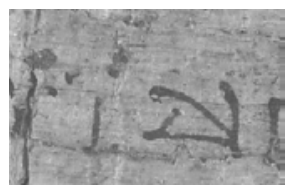

fig. 4

Supralinear dots have also been added. ${ }^{11}$ The lighter colour of the supralinear dots when contrasted to the letters of the text (clearer in the original); a different pen used (broader, see for example fig. 4, col. i 35) and the differences in the tone of the dots of the dieresis over the iota contrasted with the supralinear dots in line 34 (lighter), all suggest a subsequent placement of the dots by another hand. Various proposals have been put forward as to the meaning and function of the supralinear dots. ${ }^{12} \mathrm{D}$. Jourdan-Hemmerdinger (1979) has proposed that the supralinear dots in P.Lond.Lit. 207 act as musical notes. From her reading of the manuscript she proposes that the dots are placed at different levels to correspond to various musical notes. She distinguishes seven different levels (in relation to notional alignment of the letters). However, it may also be observed that just as the various letters 'fall' and 'rise' without any apparent significance, so do the dots, cf. col. ii, lines 11-13, see fig. 5 .

\footnotetext{
${ }^{10}$ Rea (1984: 35) places the hand of P.Oxy.51 3614 in the third century.

${ }^{11}$ For my re-edition of the placement of the dots see the appendix. Supralinear dots used variously are also found in the following papyri: P.Oxy.7. 1008 (IV), a small comma that often is written as a dot is employed to separate syllables when consonants occur in juxtaposition; PSI 2.124 (III/IV), supralinear dots are used as editorial marks to show omissions. Schøyen 123 , supralinear dots show corrections. P.Oxy. 5 843, high dots used to mark a pause. The supralinear dots in P.Lond.Lit. 207 appear to mark syllables, see Cribiore 1996: 245 and 87 for other examples.

12 Kenyon (1900: 1) suggests that they may have been added as an aid to singing (as an alternative to reading) in school. Cribiore (1996: 297) takes the dots to be teachers' models to aid reading.
} 


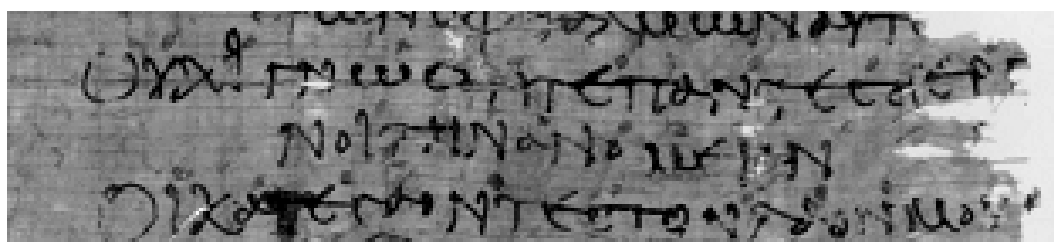

fig. 5 showing col. ii $10-13$

Following Cribiore's suggestion, it is much more likely that both texts are teachers' models and the dots have been placed in the text to mark off the syllables as an aid in reading. ${ }^{13}$ This suggestion gains weight when we note that on the back of the papyrus sheet (P.Lond.Lit. 255) there is written across the fibres a popular work used for school exercises, a section from the Ad Demonicum, a work by the fourth century BC orator Isocrates. There the text has been written with medial dots marking off the syllables. ${ }^{14}$

\section{The nomina sacra in P.Lond.Lit. 207}

In P.Lond.Lit. 207, кú@ıoৎ is always treated as a nomen sacrum but significantly $\theta \varepsilon$ có is not, except in col. i 35, however when the writing style is examined it is apparent that the correction, $\overline{\theta v}$, in col. i 35 (fig. 6) has been written by a second hand.

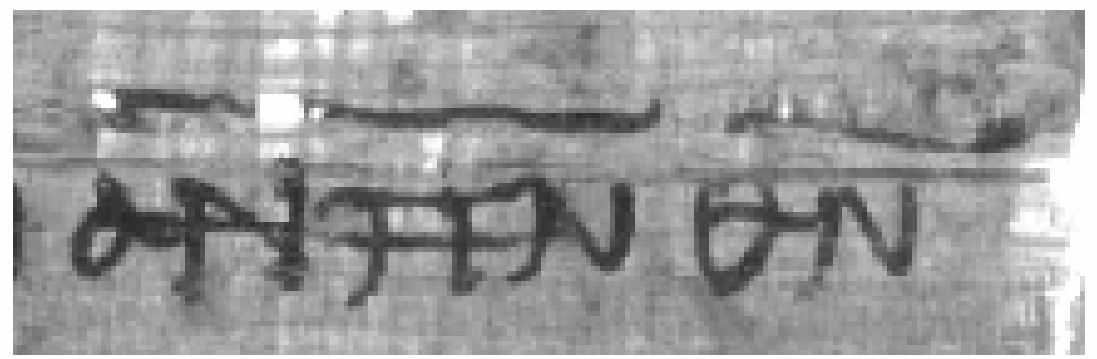

fig. 6 , col. i 35

Theta occurs eight times in the text of P.Lond.Lit. 207 (see below).

\footnotetext{
${ }^{13}$ Cf. Cribiore 1996: 126.

${ }^{14}$ The opening work in the Isocratean corpus is strong in maxims. The twenty-two known papyri are listed in Worp \& Rijksbaron 1997: 50, and its use studied by Pruneti (1986: 211-219).
} 


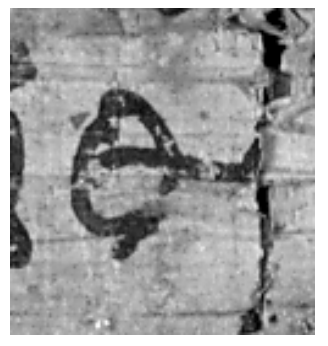

fig. 7, col. i 9

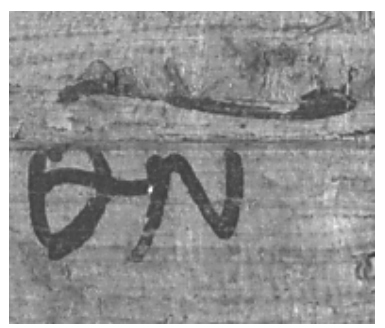

fig. 11, col. i 35

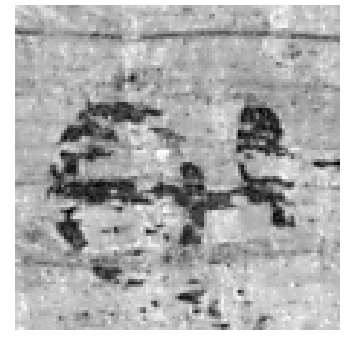

fig. 8, col. i 15

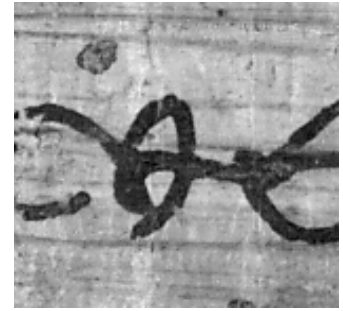

fig. 12 , col. ii 9

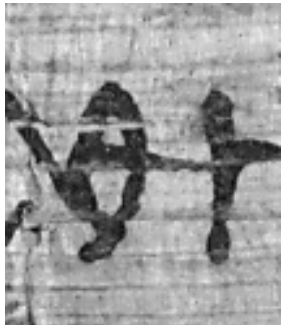

fig. 9, col. i 31

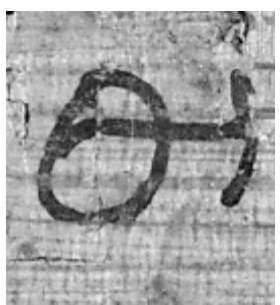

fig. 13 , col. ii 24

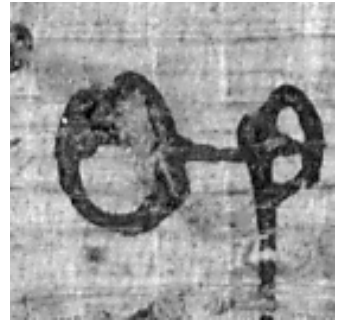

fig. 10, col. i 34

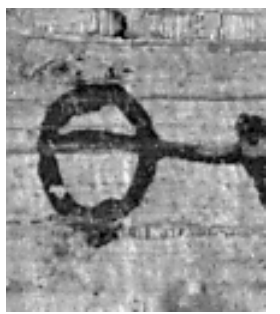

fig. 14 , col. ii 30

Theta in all cases, including col. i 35 (fig. 11), is formed by three strokes..$^{15}$ The first is a downward semicircular stroke forming the left side of the circle of the theta. This stroke varies from a deep (see fig. 15) to a shallow semicircle (see fig. 16).

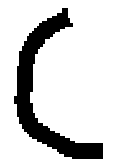

fig. 15

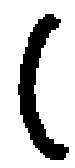

fig. 16

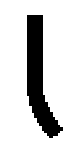

fig. 17

The second stroke is another semicircular stroke forming the right side of the circle. Again this stroke varies in the same way resulting in either a circle (fig. 7) or an oval shape (fig. 8). Lastly, a horizontal stroke is drawn that extends to the following word.

When we compare the formation of the theta and the supralinear bar of the first hand with the theta and the supralinear bar in col. i 35 (fig. 11) we may observe three significant mis-matches on the level of the fine detail of letter formation, which suggests that it was written by another hand. Firstly, the left hand stroke to form the circle is almost vertical in contrast to the first stroke of the first hand (see fig. 17) This has the effect of making the resultant circle egg shaped with the top broader than the bottom. Secondly, the horizontal bar that is written by the first hand to complete the theta begins with a slight curve and then is drawn as a straight line (see fig. 18). However, in the case of the theta in col. i 35, the horizontal bar is drawn as a wave (see fig. 19).

\footnotetext{
${ }^{15}$ See Cribiore 1996: 108 for the way in which students were taught to form the theta.
} 


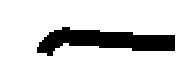

fig. 18

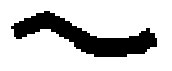

fig. 19

Thirdly, the horizontal supralinear bar written by the first hand to mark a nomen sacrum is formed by drawing a near horizontal line which begins and ends with a serif. The serif is either sublinear or level with the bar, see fig. 20, 21, 22, 23, 24, 25, 26, 27. In contrast, however, the supralinear bar placed over the nomen sacrum in col. i 35 (fig. 28) has a quite distinct curve and is written in a much more confident manner with a final supralinear serif.

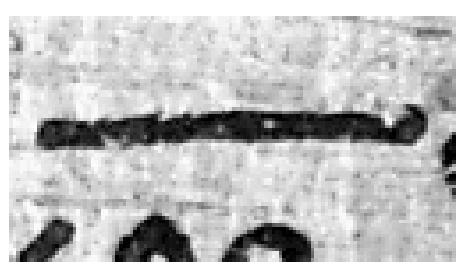

fig. 20, col. i 1

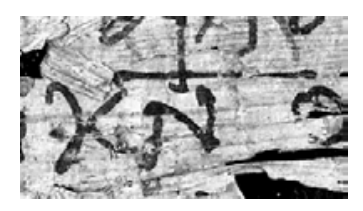

fig. 23 , col. i 35

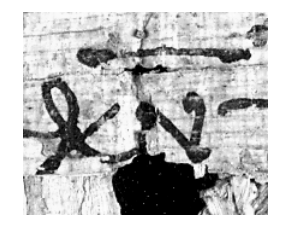

fig. 26, col. ii 22

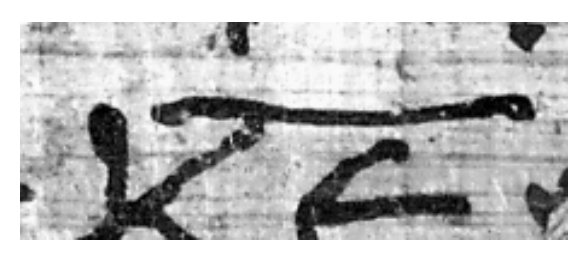

fig. 21, col. i 12

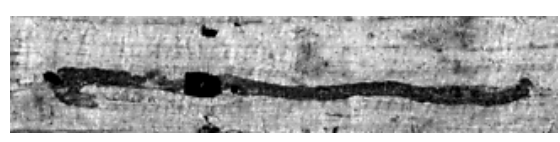

fig. 24 , col. ii 15

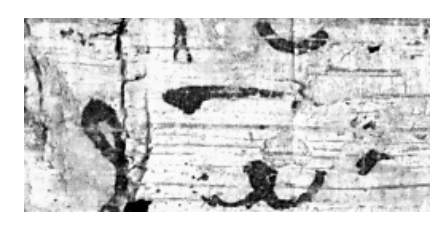

fig. 22, col. i 25

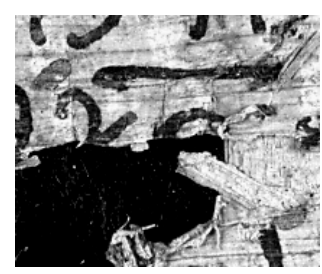

fig. 25 , col. ii 19

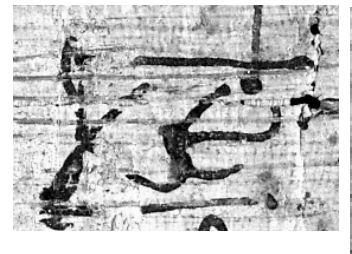

fig. 27 , col. ii 26

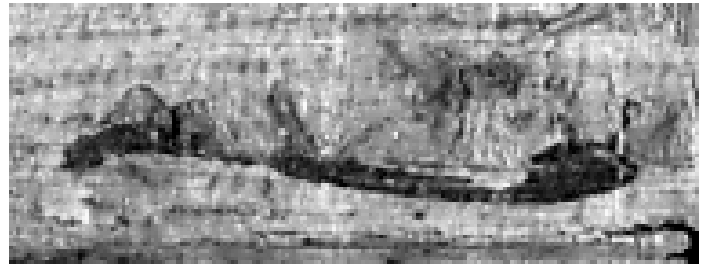

fig. 28, col. i 35 over the nomen sacrum $\Theta \mathrm{N}$

From the above observations we can confidently conclude that the nomen sacrum of col. i 35 was inserted by a second hand. Therefore of the four occurences of $\theta \varepsilon$ có in P.Lond. Lit. 207 in three cases (col. i 16, col. i 30 and col. ii 9) the word is written by the first hand and is always written out in full. (In col. i 16 and col. i 30, $\theta \varepsilon$ có can be confidently restored from the remaing ink traces as being uncontracted, see fig. 29-32.) In the one case where it is contracted as a nomen sacrum it has been written by a subsequent corrector. On the other hand, kú @ıos occurs nine times in the text and is always written as a nomen sacrum. The other word that is written as a nomen sacrum is áv $\theta 0 \omega \pi$ o and it is treated variously. In col. i 34 it is written uncontracted. As discussed above, however, in the next line it has been written as a nomen sacrum and then corrected by a different hand with $\theta \varepsilon$ cov, written 
as a nomen sacrum (fig. 5). The inconsistency and the incorrect insertion in the text of the nomen sacrum, $\overline{\alpha v} \bar{\tau} \bar{v}$, may perhaps be explained by a mental distraction on the part of the

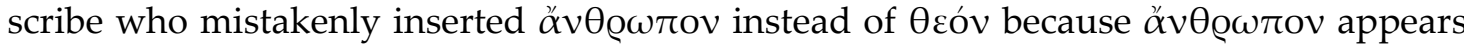
at the end of the line above and, being accustomed in other contexts to write äv $\theta \varrho \omega \pi \circ \mathrm{v}$ as a nomen sacrum, did so here.

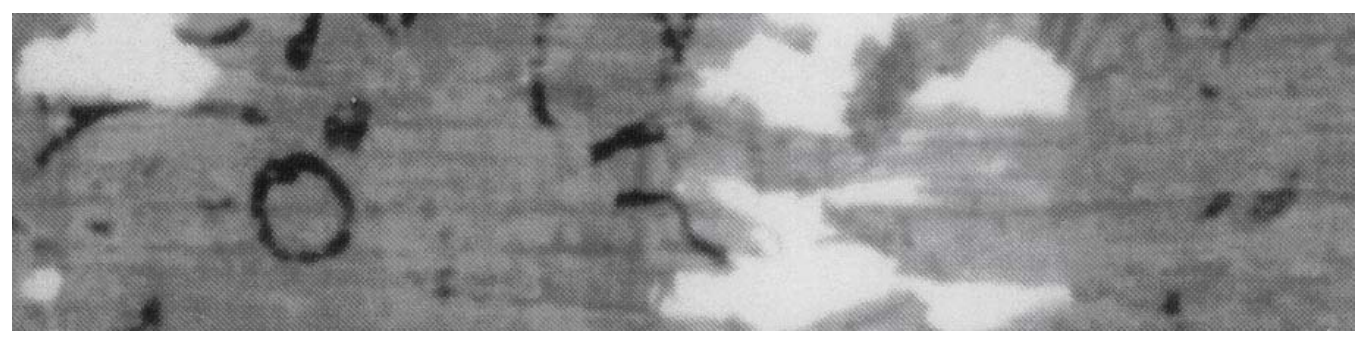

fig. 29 , col. i 16

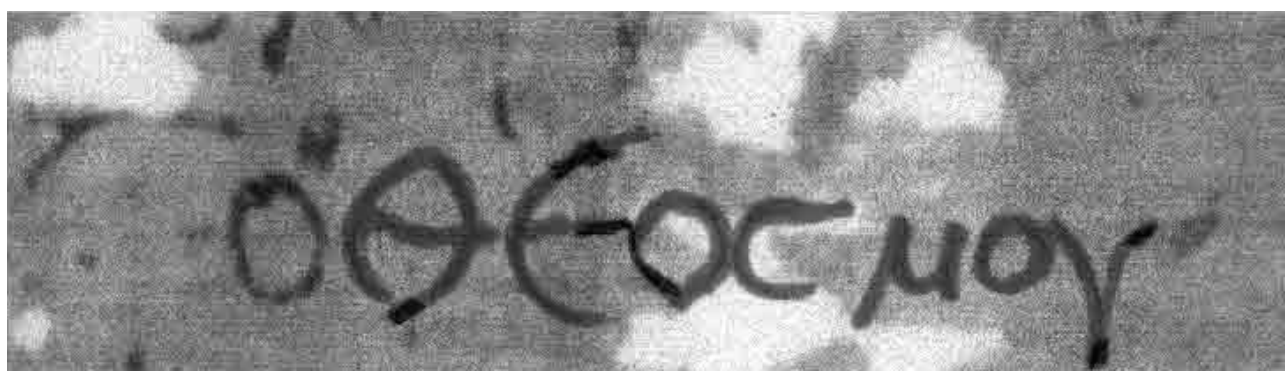

fig. 30, col. i 16 reconstruction

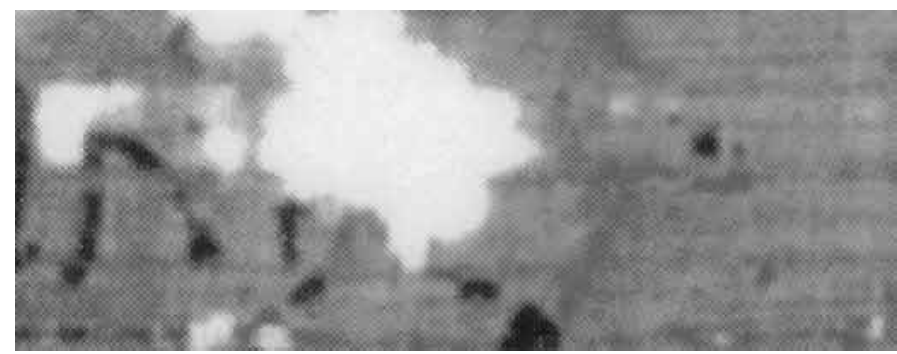

fig. 31, col. i 30

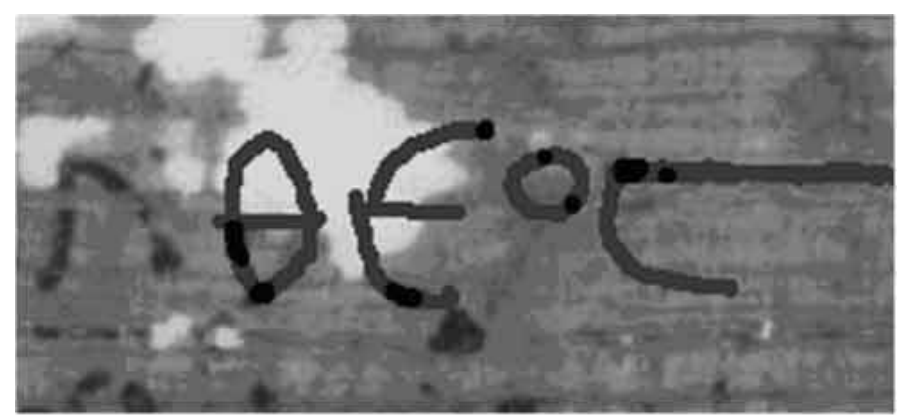

fig. 32, col. i 30 reconstruction 


\section{Conclusion}

Why is $\theta \varepsilon$ có, which is always treated in Christian texts as a nomen sacrum, written uncontracted in P.Lond.Lit. 207 by the first hand, whilst kúpıoৎ is consistently written in a contracted form using the first and last letters? Perhaps the answer to the question is to be found in the Hebrew word that kúpıs in the Greek Old Testament translates, the Tetragrammaton, which is the personal name of the Hebrew deity. Judging by the various ways the Tetragrammaton was written in the text of the Greek Old Testament, it appears that scribes struggled with the problem of how to present it. Some left a space in which the Hebrew word was to be written later; others used paleo-Hebrew writing, whilst

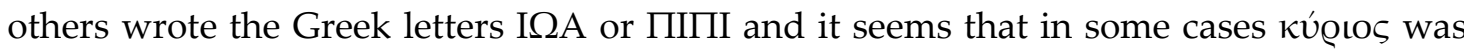
used instead of the Tetragrammaton. ${ }^{16}$ But why write kúpıos in a contracted form using the first and last letters as it is in P.Lond.Lit. 207? Do we have a precedent for such a contraction? A. Millard has drawn our attention to the peculiar Semitic custom of contracting proper names to their first and last letters. It is found on Phoenician and Palestinian coins of the Hellenistic period and also on pots in the Punic Sites of North Africa where they occasionally also occur on coins and graffiti. ${ }^{17} \mathrm{Did}$ a scribe or scribes use this contracted form for personal names to signal to the reader that kú tracted, is being used for the personal name of the Hebrew deity and so distinguish it from its usual non-personal use as master or lord? If so, could it be that P.Lond.Lit. 207, in contracting kúgıo in this Semitic fashion, preserves a very early use of this custom? This would explain why $\theta \varepsilon$ ó $\varsigma$ is consistently left uncontracted in P.Lond.Lit. 207. Of course in time $\theta \varepsilon$ ć $\varsigma$ was also abbreviated in the same way as kú@ı of its close association with it. Perhaps the use of this Semitic custom for personalising

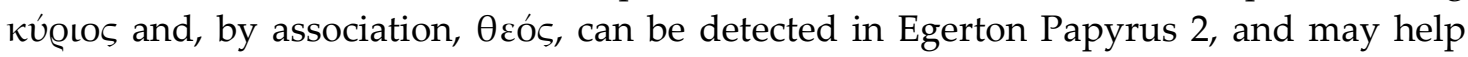
explain the diversity of abbreviations in this manuscript. ${ }^{18}$ The abbreviated words used in Egerton Papyrus 2 can be classified into three groups. Firstly, words abbreviated in

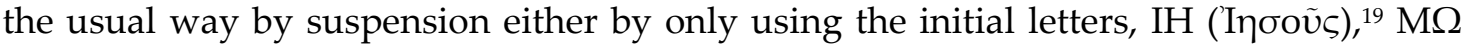

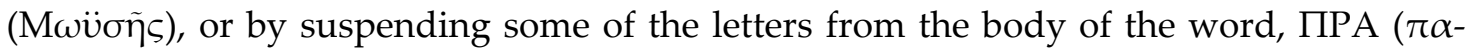

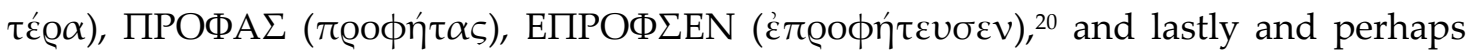

\footnotetext{
16 Pietersma 1984: 85-101.

${ }^{17}$ For raising this possibility as to the way nomina sacra are abbreviated see Millard 2001: 71 and Millard 1994: 221-26.

${ }^{18}$ Egerton Papyrus 2 has been dated by the initial publishers, Bell and Skeat, as not later than AD 150 and perhaps as early as AD 94 (Bell \& Skeat 1935), however the recent discovery of an additional fragment, published by Michael Gronewald (1987: 136-45), has led some papyrologists to revise the dating of the document to c. 200.

${ }^{19}$ Bell \& Skeat (1935: 3) note that this is a rare form and may be of early origin. Hurtado (1998: 655-73) has argued that the abbreviation IH with a supralinear bar was used to signify that its numerical value was the same as the numerical value of the Hebrew word 'life'. However, if Egerton Papyrus 2 conveys a very early use of abbreviations, Hurtado's proposal does not explain why the name Moses is so abbreviated.

${ }^{20}$ For examples see Avi-Yonah 1940: 21-22.
} 
significantly, kú@ı

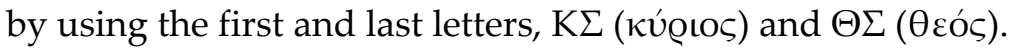

\section{Dr. Don C. Barker}

Department of Ancient History, Macquarie University

E-mail: Don.Barker@humn.mq.edu.au

\section{Bibliography}

Avi-Yonah, M. (1940) Abbreviations in Greek inscriptions - The Near East, 200 B.C. - A.D. 1000. (Quarterly of the Department of Antiquities in Palestine; supp. 9.) London: Oxford University Press; Jerusalem: Government of Palestine.

Bell, H. I.; Skeat, T. C. (1935) Fragments of an unknown Gospel and other early Christian papyri. London: British Museum.

Brown, S. (1970) 'Concerning the origin of the nomina sacra.' - Studia papyrologica 9, 7-19.

Comfort, P. (2005) Encountering the manuscripts: an introduction to New Testament paleography \& textual criticism. Nashville, Tenn.: Broadman \& Holman.

Cribiore, R. (1996) Writing, teachers, and students in Graeco-Roman Egypt. (American studies in papyrology; 36.) Atlanta, Ga.: Scholars Press.

Gronewald, M. (1987) ‘Unbekanntes Evangelium oder Evangelienharmonie (Fragment aus dem 'Evangelium Egerton').' - Kölner Papyri, Vol. VI. Köln: Rheinisch-Westfälische Akademie der Wissenschaften, 136-145.

Hurtado, L. W. (1998) 'The origin of the nomina sacra: a proposal.' - Journal of Biblical Literature $117.4,655-73$.

Jourdan-Hemmerdinger, D. (1979) 'Nouveaux fragments musicaux sur papyrus (une notation antique par points).' - Wellesz, E. et al. (eds.), Studies in Eastern Chant 4, 81111.

Kenyon, F. G. (1900) Facsimiles of Biblical manuscripts in the British Museum. London: British Museum.

Millard, A. (1994) 'Ancient abbreviations and the nomina sacra.' - Eyre, C. J.; Leahy, M. A.; Leahy, L. M. (eds.), The unbroken reed: studies in the culture and heritage of Ancient Egypt in honour of A. F. Shore. (Egypt Exploration Society, Occasional publications; 11.) London: Egyptian Exploration Society, 221-26.

Millard, A. (2001) Reading and writing in the time of Jesus. Sheffield: Sheffield Academic Press.

Paap, A. H. R. E. (1959) Nomina sacra in the Greek papyri of the first five centuries A.D.: the sources and some deductions. (Papyrologica Lugduno-Batava; 8.) Leiden: Brill.

Pietersma, A. (1984) 'Kyrios or Tetragram: a renewed quest for the original Septuagint.' - Pietersma, A.; Cox, C. (eds.), De septuaginta: studies in honour of John William Wevers on his sixty-fifth birthday. Mississauga Ont.: Benben Publications, 85-101. 
Pruneti, P. (1986) 'L'Ad Demonicum nella scuola antica: esempi di utilizzazione.' - Munus amicitiae: scritti in memoria di Alessandro Ronconi. Vol. I. (Quaderni di filologia latina; 4.) Firenze: Le Monnier, 211-219.

Rea, J. R. (1984) The Oxyrhynchus Papyri LI: nos. 3601-3646. London: Oxford University Press.

Roberts, C. H. (1979) Manuscript, society and belief in early Christian Egypt. Oxford: Oxford University Press.

Traube, L. (1907) Nomina sacra: Versuch einer Geschichte der christlichen Kürzung. (Quellen und Untersuchungen zur lateinischen Philologie des Mittelalters; 2.). München: Beck.

Worp K. A.; Rijksbaron, A. (eds.) (1997) The Kellis Isocrates codex (P.Kell. III Gr.95). (Dakhleh Oasis Project; 5.) Oxford: Oxbow Books. 


\section{Appendix \\ Transcription of P.Lit.Lond. $207^{21}$}

Col. i

Ps. 11(12)

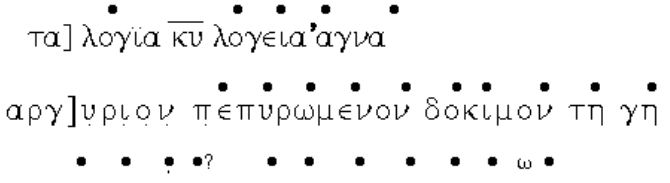

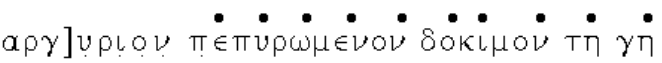

$\bullet \cdot \bullet \cdot \bullet \cdot \bullet \cdot \bullet \omega \cdot$

$\kappa] \in \kappa a \theta \alpha \rho L \sigma \mu \in V o \nu \in \pi T \alpha \pi \lambda \alpha \sigma L O \nu$

$\sigma \dot{v} \overline{\kappa \epsilon} \phi u \dot{\lambda} \xi\llcorner\dot{s} \overline{\eta \mu} \dot{s}$

5

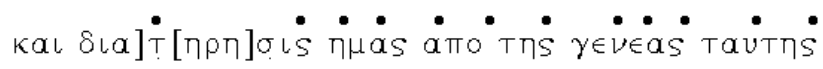

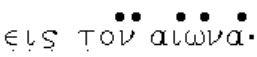

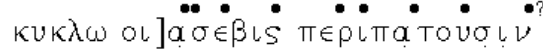

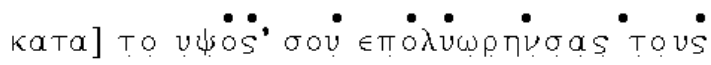

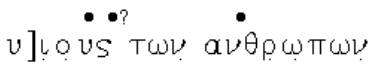

Ps. 12(13)

10

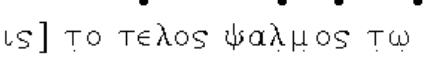

$$
\Delta a \dot{v} \in \text { T }^{*}
$$

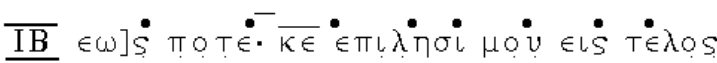

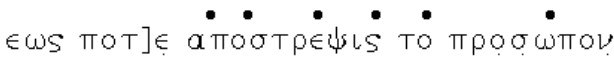

$$
\sigma \circ v \dot{a}] \pi \dot{\epsilon} \mu \dot{v}
$$

15

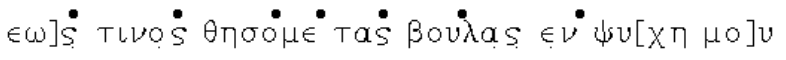

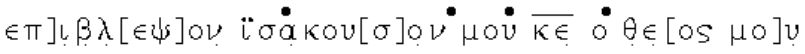

$$
\begin{aligned}
& \text { osvvas] } \epsilon \dot{v} \kappa a p \delta \in \mathrm{L} \dot{\alpha} \mu \dot{v} \dot{\eta} \mu \dot{\epsilon} \in[s]
\end{aligned}
$$

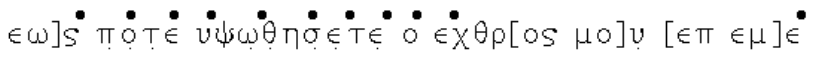

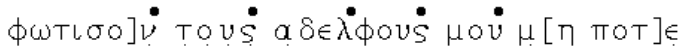

${ }^{21}$ This transcription is a result of my own autopsy of P.Lit.Lond. 207 in the British Library, London. 
20

$v] \pi \operatorname{vi}[\sigma \omega \sigma \iota] \dot{v} \in \iota \dot{S} \theta \dot{\alpha} v \alpha[T o v]]^{\bullet ?}$

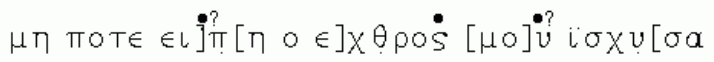

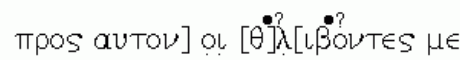

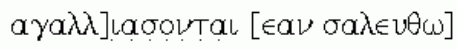

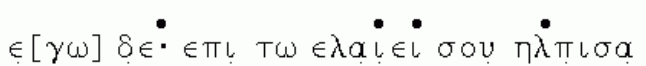

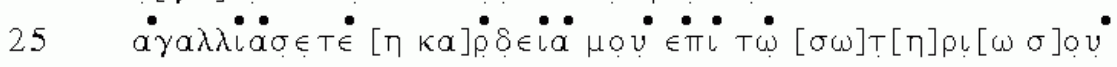

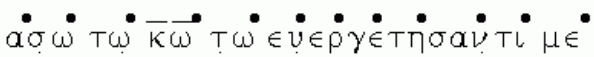

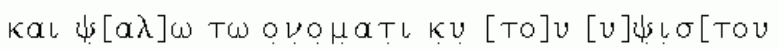

is to $T \in \lambda \circ S T \omega \Delta a v \in L \delta$

Ps.13 (14)

$\psi \alpha \lambda \mu \circ$

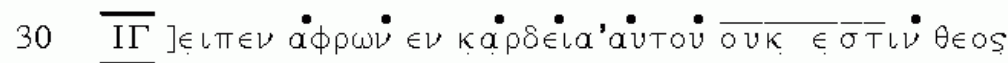

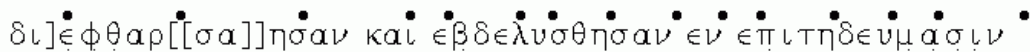

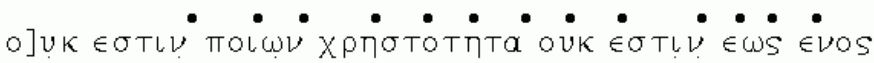

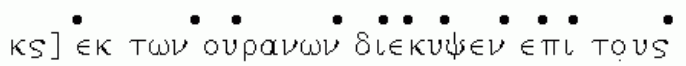

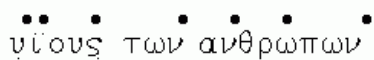

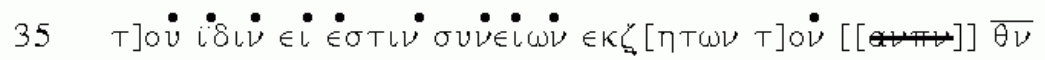

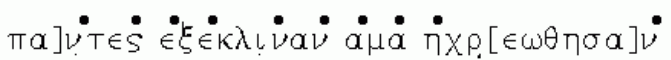

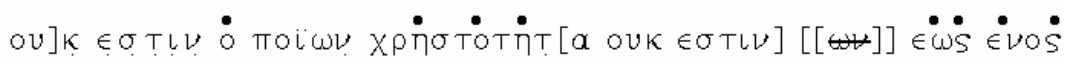

Col. ii

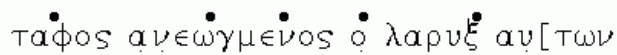

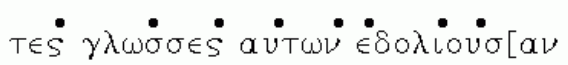

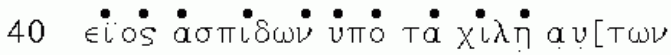

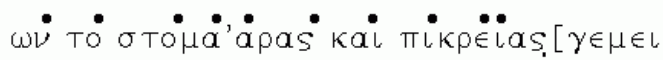




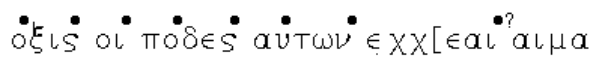

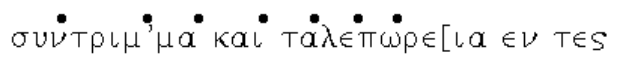

- sois aútwi

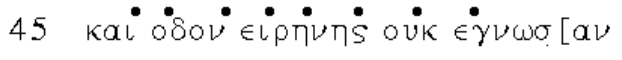

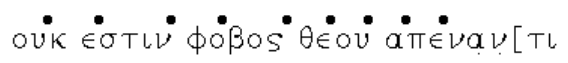

TwV

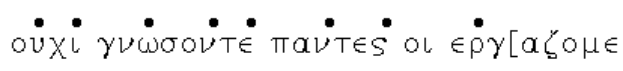

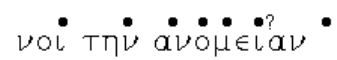

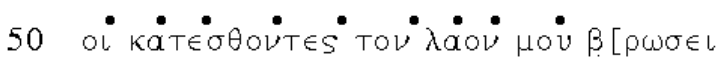

aрंтo:

Tov $\bar{\kappa} \bar{\nu}$ ouk $\dot{\epsilon} \pi \dot{\epsilon} \operatorname{a} \lambda \epsilon \sigma \alpha \nu[T o$

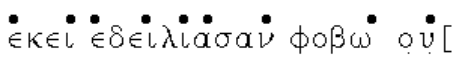

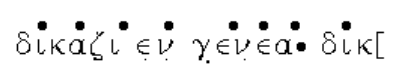

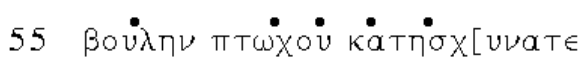

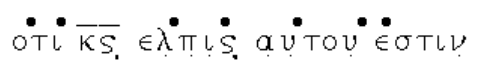

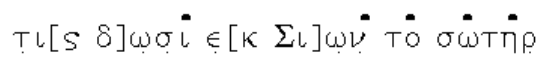

iòv $[$ lo]pa d

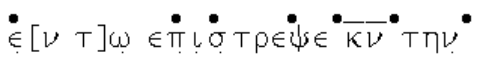

$60 \quad \alpha\lfloor\chi \mu \alpha \lambda \omega \sigma]\llcorner\alpha \psi[$ Tov $\lambda a \circ v$ avтov

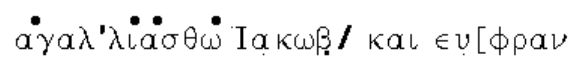

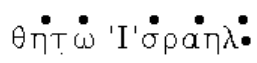




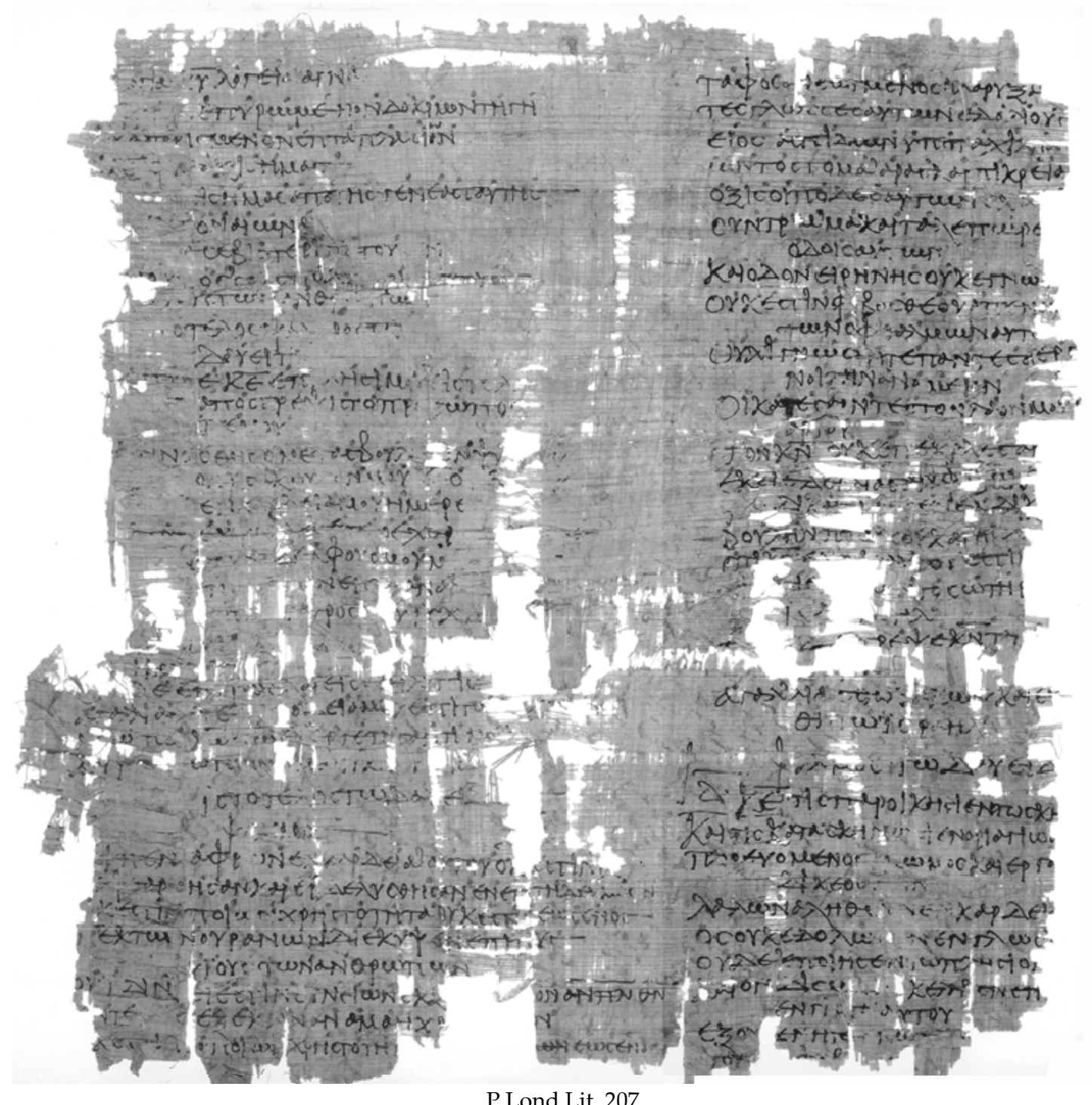

P.Lond.Lit. 207 